\title{
Social Recognition Research in Foreign Marriage for Transnational Groups in China-Vietnam Border
}

\author{
He Xiaobo \\ Yunnan University of Finance and Economics \\ Kunming, P.R. China 650221 \\ hexiaobo921@hotmail.com
}

\begin{abstract}
Due to next region, economic and trade communication, similar living style and stable marriage circle history, foreign marriage has been existed for a long time in China-Vietnam border, especially for the transnational groups. It plays an important role in border stability and transnational communication, but also some serious social problems have been drawn government and experts' attention. The passage is based on the perspective of social recognition to analyze the transnational groups' foreign marriage certification from the four dimensions as constitutions, economy base, self-value and society. Consequently, five suggestions as government policy, public opinion propagation, and culture communication to support folk organization, making founded law policy and developing economy are given to solve the social recognition plight
\end{abstract}

Keywords—social recognition, foreign marriage, transnational groups, China-Vietnam border, marriage circle

Case Origin: Case of Yunnan University of Finance and Economics Doctorate Degree Establishment: Social and Cultural Management in Border Areas of South West Regions in china

Foreign marriage has been existed for a long time in ChinaVietnam border because of next region, economic and trade communication, similar living style and stable marriage circle history. It serves as a bridge to enhance two countries' communication and has thousands of families in happiness. However, some social problems also exist at the same time behind the transnational marriage. Social recognition is one of the serious problems. The research in foreign marriage for transnational groups is full of significance for border stability, nation unity, family happiness, personal values and social management.

\section{INTRODUCTION OF TRANSNATIONAL GROUPS IN CHINA- VIETNAM BORDER}

Yunnan is the province has the most minorities in China. There are 25 minorities whose population is over 5000 except Han people. According to the data of the sixth national population census investigation in 2010, Yunnan has the population of 14.33 million for minorities which is amount to the 1 in 3 of the total population in Yunnan province. Among the minorities, the population is over 1 million are the minorities such as Yi, Bai, Hani, Dai, Zhuang and Miao people. The minorities whose population is between 0.1 to 1 million are Lisu, Hui, Lahu, Wa, Naxi, Yao, Jinpo and Zang people. Yunnan has several neighbor countries as Myanmar, Laos,
Vietnam, Thailand and India. The border is $3207 \mathrm{kms}$ in total. Among it, China-Vietnam border is 710 kms. Yunnan has 117 counties, and 27 of them lie to Myanmar, Laos and Vietnam. [1] Among the 26 minorities in Yunnan, thousands of people are in transnational marriage and family to live in borders.

It is controversial about the definition of transnational group. In my viewpoint, it is supposed to include the concept of the minority people who live in the neighbor county and the close relations of their blood, religion, living styles and so on. To some extent, although the transnational group has belonged to two different countries, they are the similar and even the same ethnic groups, such as Miao, Hani, Dai people and so on.

The transnational group in Yunan always has its own selfname. Sometime they live in two different countries and have the different so-called name. The transnational group people have been divided into different countries, but the living region is close and similar. According to the definition of above about transnational group, there are 16 transnational groups whose population is over 5000 in Yunnan province. However, only 12 minority groups are living in China-Vietnam border. They are Han, Miao, Yao, Yi, Hani, Lahu, Hui, Zhuang, Dai Buyi, Yao, Gelao, Jin people, and the population of the 12 minority groups are less than 2 million. [2]

\section{REASONS FOR TRANSNATIONAL GROUPS’ FOREIGN MARRIAGE IN CHINA- VIETNAM}

\section{A. Near Regional Neighbor Relations}

In history, Vietnam once was belonged to China. Since France has governed Vietnam in the end of Qing dynasty, and signed the border agreement for the two countries, the concept of border has been come out. There are 12 transnational groups along the border of China-Vietnam. These transnational groups have different names based on different division measures. However, it is impossible to stop the connection and communication of the two countries' people. According to the research of Fan Honggui, "The touch and communication are divided into two natures-economy and emotion. In the border of China-Vietnam, people have to enter the other county by visa in the national and provincial port. Besides, in the long border, it assumes that there are hundreds of lanes to go across the two countries. There avenues and lanes are mixed and connected with each other. It is a blank margin for the two countries' governing, but it is convenient for the two countries' people to communicate.” 


\section{B. Trade and Economic Communication}

Since 1990s, China has enhanced the economic and trade connections with Southeast Asia free trade countries, especially with the south Southeast Asia continental countries. The trade and economic communication for transnational regions has been enhanced more and more. In the condition, the transnational activity has been more and more frequent, which has reduced the nation boundary. Non-boundary has improved the two nations' economic, social and cultural mixture. Recently with the development of China's economy, more and more Vietnam girls are willing to marry Chinese man. It is rarely for Chinese man to marry Vietnam girls and live together in Vietnam.

\section{Similar Living Styles}

For the transnational groups in the border of ChinaVietnam, even though some minorities have different names according to their own country definition. In fact, some of them are the same group origin, similar living styles, customs and religions. Consequently, it is not a difficulty for the transnational groups to marry and live in the border. They can communicate very well. Similar living styles have made foreigner be familiar with the native life and mix with the native as soon as possible. In the similar living styles, language and customs are the most important two sorts to evaluate people to mix with the native.

\section{The Stable Marriage Circle Based on Ethnic Cultures}

In the space investigation of arranged marriage, it is obvious that the folk traditional marriage always has its own and stable space circle, which is called marriage circle. Indeed, marriage circle stands for the relative fasten exchange for several different villages. Because of the stable marriage circle, the institution of clans, relatives and marriage has been formed. Marriage circle not only has the importance of space connection but also the significance of social communication. With the development of society, marriage circle can be in the space or social transformation. More and more people pay attention to others' social status, good-looking and education rather than the traditional marriage circle mode.

\section{SOCIAL RECOGNITION PLIGHT FOR THE TRANSNATIONAL GROUPS’ FOREIGN MARRIAGE IN CHINA-VIETNAM BORDER}

\section{A. Social Institution Recognition}

Political recognition and marriage institution are the most important dimensions of social institution recognition. [3] Political recognition minority focuses on the perspective of a nation. For a nation or minority group whose main people are distributed into a single nation, it is easy to get a nation or minority's political status recognition. However, it is more difficult and complicated for the transnational groups to get the identity. Because of the definition of border, it enables the transnational people have different identity. For the Vietnam brides who are willing to marry into China, they would lose their Vietnam identity. But not everybody marrying into China can get the political identity, because most transnational marriage for the border people are fact marriage. Their marriage is only a kind of tradition of marriage circle. [4]

\section{B. Economic Recognition}

Economic base is the most important tool to evaluate people's social status in any dynasty and society. If one gets a low pay or earn nothing, especially for the women, it is difficult for them to have a high social status from their husband's family and society entered into. For most Vietnam brides, when they live in Vietnam, their living style is almost farming. Rice,fruit, rubber planting are three the most important living ways. It is obvious their life has to be established on the base of land. They have own land in Vietnam. But when they marry into China, they lose their rights of owning a piece of land, and because of the illegal marriage, they can not get the land rights to plant from China government. They have to depend on their husband and family. At the same time,if the Vietnam girls marry into China and attend a non-farming life,they have to stay into the family itself for baby care. Otherwise, they engaged business rather than themselves but also with their husband, especially for the new comer who are not frequent in Chinese language.

\section{Self-value Recognition}

Vietnam is less developed country comparing with China. Most Vietnam people are poorer than Chinese people, that's why thousands of Vietnam girls want to marry into China. Due to the lower quality life, poor economy, undeveloped education, although they marry into China, they are not confident. In the investigation of the paper, most Vietnam brides restricted their communication circle. In daily life, they stay in family and communication with their relatives or the same identity women in village. They do not think they are the same comparing with other Chinese brides. In fact, they are not confident. They live along and feel lonely.

\section{Cultural Recognition}

Transnational minorities are special cultural groups. For one thing, cultural recognition means to adopt and accept the transnational minorities' minor culture for they have an original culture in their country and ethnic group. For another, cultural recognition also means to adopt and accept the dominant culture after they marry into China. There is always a large differentiation for minority culture and dominant culture. Some researchers hold that the investigation minor and dominant culture are the most important ways to reduce the social differentiation. It is a piece of good news that most Vietnam brides and the similar religion culture comparing with Chinese border people. Religion is one of the most important dimensions of culture and psychology. Because of the similar recognition and customs culture, the Vietnam bride can't be accepted easily by the native. However there is a long way to mix with the local society for religion is just a part of culture.

\section{E. Society Recognition}

It is easy to accept the Vietnam brides for the husband and their family member. But it is not easy for society to recognize them for the number of foreign marriage in transnational groups is very common but also minor comparing with other districts in China. For most Vietnam brides, they have no political recognition. Their children are not the legal children. It is so hard for their children to enjoy the fair and equal 
education rights as other children. Even in the nick name for their children, "Yuenan Mei”, "Yuenan Zai” and "Yuenan Po" are some common names to be looked down up on.

\section{MEASURES AND SOLUTIONS FOR TRANSNATIONAL GROUPS' SOCIAL RECOGNITION}

\section{A. Government Should Make Professional Policy to Ensure Foreign Marriage in Equal Rights}

To some extent, Chinese government is short of a sounded system to guarantee the transnational minorities' foreign marriage be in equal right as Chinese. The institution recognition is a complex course needing a long time and a lot of procedures. Most Vietnam brides and their husband think about it is so difficult even impossible to get Chinese government recognition. Without the certification from government, they can live together all the same, which lets them be in fact marriage. Consequently, Chinese government should make the short and convenient policy to meet their needs.

\section{B. Enhancing the Public Opinion Propagation}

In modern society the mass media as newspapers, magazines, TV, broadcast, network, book have really done a great effect to everybody including border people. So government and society should enhance the public opinion propagation and make people to know about policy and events as soon as possible and let them in. After that, government would set an example to treat the transnational groups' foreign marriage and daily life. Other folk organizations and strength would follow as the example to accept the Vietnam brides to mix into the local society better.

\section{Fortifying the Cultural Communication and Supporting Folk Organizations to Mix Different Cultures}

China has many serious social problems such as gender imbalance recently. Foreign marriage from Vietnam maybe is a good way to keep the balance and make more families in happiness. Although it is a history for Vietnam girls to marry into China and from a fasten marriage circle. But it is almost overwhelm for the border people to own the social status in marriage. More folk organizations can do better in culture integration than government does in some time. More understanding, communication, supporting, win-win profits would make the two nation's culture in a good integration and a long friendship.

\section{Making Founded Law Policy to Ensure Legal Foreign Marriage and Punish Illegal Foreign Marriage}

The imbalance of sex ration in China is another key reason for drawing Vietnam girl's attention to marry into China.
Consequently, Chinese government should welcome the foreign marriage form in order to solve Chinese man's marriage plight. However, legal foreign marriage is just a small part in the total people in transnational marriage. More Vietnam girls marry into China without any official legal procedures, and for this reason their rights can not be guaranteed by government, which leads that they are difficult in social recognition from China. Meanwhile, the legal marriages as fact marriage make Chinese government difficult in management. Therefore, it is necessary to make founded law policy to ensure legal foreign marriage and punish illegal foreign marriage.

\section{E. Developing Economy Is the Key Reason to Make Foreign Marriage in Natural Fluctuation.}

The reason for explaining why so many Vietnam girls married into China, economy is the most important reason. Vietnam girls are eager to change the poor life as they have in original country. For most girls, they marry into China without any marriage elements as love. But love is the most important element for lovers to establish marriage and family. However, even some of the Vietnam girls are not familiar with their husband when they would hold weddings. Recently, more and more Vietnam bridegrooms go back their original country after weeding, which lays their new-formed family in unstable risk.

\section{CONCLUSION}

All in all, foreign marriage has existed for a long time in the border between China and Vietnam. Most transnational marriage plays an important and good role in the two nations' marriage, family and local society. Chinese government and Vietnam government should realize the tradition and tendency to encourage legal foreign marriage, but some illegal fact marriages are also the challenge for the stability of local family and society. Government and social recognition are the two most important measures to make legal transnational marriage. To some extent, government policy and social recognition should be mutual. If the foreign marriages for transnational groups are in good social recognition, it will be in a good recycle and make the two nations in win-win condition.

\section{REFERENCES}

[1] Zhou Jianxin, Ethnic Group Relations Research for Transnational Group in China-Vietnam Border, [M] Beijing: Minzu Press, 2002, P34. (In Chinese)

[2] Huang Zheng, Xiao Debao, Chinan-Vietnam Border Historical Materials Selection,[M] Beijing: Social Science Academic Press,1993, P12. (In Chinese)

[3] Zhao Lisheng,Ethnic Sociology, [M] Beijing: Minzu Press, 2009, P124. (In Chinese)

[4] Fang Honggui, Introduction of Transnational Groups for China and Vietnam , [J] Ethnic Group Research,1999.(In Chinese) 